DOI: $10.2478 / \mathrm{v} 10047-011-0029-2$

\title{
GALACTIC COSMIC RAY MODULATION UP TO RECENT SOLAR CYCLES
}

\author{
R. Agarwal ${ }^{1}$, R.K. Mishra ${ }^{2}$ \\ ${ }^{1}$ Department of Physics, Govt. Model Science College (Autonomous), \\ Jabalpur (M.P.) 482 001, INDIA \\ ${ }^{2}$ Computer and IT Section, Tropical Forest Research Institute, \\ P.O.: RFRC, Mandla Road, Jabalpur (M.P.) 482 021, INDIA \\ e-mail:rkm_30@yahoo.com or rajeshkmishra20@hotmail.com
}

\begin{abstract}
Cosmic ray neutron monitor counts obtained by different ground-based detectors have been used to study the galactic cosmic ray modulation during the last four solar activity cycles. Since long, systematic correlative studies have been performed to establish a significant relationship between the cosmic ray intensity and different helio-spheric activity parameters, and the study is extended to a recent solar cycle (23). In the present work, the yearly average of $10.7 \mathrm{~cm}$ solar radio flux and the interplanetary magnetic field strength (IMF, B) have been used to find correlation of the yearly average cosmic ray intensity derived from different neutron monitors. It is found that for four solar cycles $(20-23)$ the cosmic ray intensity is anti-correlated with the $10.7 \mathrm{~cm}$ solar radio flux and the IMF, B value with some discrepancy. However, this is in a good positive correlation with the flux of mentioned wavelength for four different solar cycles. The IMF, B shows a weak correlation with cosmic rays for solar cycle 20, and a good anti-correlation for solar cycles 21-23.
\end{abstract}

Key words: cosmic rays, solar cycle, interplanetary magnetic field (IMF).

\section{INTRODUCTION}

Ground-based neutron monitors at several locations on the Earth are regularly monitoring cosmic rays for the last several decades. The observations so far indicate a clear solar cycle effect, with largest reductions in cosmic ray neutron monitor intensity during the sunspot maximum years, a good anti-correlation for long-term variation [1-2 and ref. therein]. The structure of recovery in the 11-year cycle of cosmic rays in relation to the state of interplanetary magnetic field (IMF) has been studied in detail by Jokipii \& Thomas [3], and further by Ahluwalia [4].

Galactic cosmic ray intensity data have been analyzed by Stozhkov et al. [5] and by Ahluwalia [4] for four consecutive solar activity minima (the period 19631998). The data obtained with a variety of detectors located at the global sites as well as the balloon altitudes are used in both the studies. A systematic decrease is observed in all data sets near the solar minimum epochs for the period 1965-1987. The observed decrease is ascribed by the authors of [5] to a supernova explosion in the near-interstellar medium; however, it is disputed by Ahluwalia [4], who ascribes it to the long-term modulation of galactic cosmic ray flux within the heliosphere by solar wind. 
The intensity of galactic cosmic rays measured on Earth is related to the Sun's cycle of activity, which is well known. The solar magnetic field flips every 11 years, and the number of sunspots and coronal mass ejections rises and falls twice in each complete 22-year cycle. The cosmic ray intensity on Earth also peaks twice every 22 years in time with the solar cycle. Cliver \& Ling [6] have discovered a quirk in this pattern; in their opinion, this is due to coronal mass ejections.

The intensity of cosmic rays varies at different time scales, from minutes to decades and even beyond. These variations can be studied using data from the ground-based neutron monitors. Berezhko et al. [7] found a significant solar cycle variation in the cosmic ray fluctuation magnitude for the 1980-1990 period, using 5-min. data from the Tixie Bay neutron monitor. A solar cycle change was also found in the spectrum of small-scale turbulence [8]. The solar cycle variation in cosmic ray fluctuations was verified for two solar cycles (1980-2002) using the data from two remote polar neutron monitors (Oulu and Tixie Bay) [9].

\section{DATA AND ANALYSIS}

The temperature- and pressure-corrected hourly data (counts of neutrons) of cosmic ray intensity from the Moscow neutron monitor have been used. The longterm change was removed from the data by the method of trend correction. The days of Forbush's decreases have also been removed from the analysis to avoid their influence on the cosmic ray variation. The data on IMF and solar wind plasma are taken from the interplanetary medium data book.

\section{RESULTS AND DISCUSSION}

Figure $1(a-e)$ shows the sunspot number $\left(\mathrm{R}_{\mathrm{z}}\right)$, the interplanetary magnetic field strength $\left(\mathrm{B}_{\mathrm{z}}\right.$ component of IMF), the disturbance storm time index $\left(\mathrm{D}_{\mathrm{st}}\right)$ and the cosmic ray intensity normalized in a suitable manner so that they are juxtaposed to represent the continuous temporal variations of cosmic rays along with different parameters over the four decades (1964-2004). Curve $1(a, b)$ for the cosmic ray intensity and $\mathrm{R}_{\mathrm{z}}$ tracks each other in an impressive manner. A major discrepancy is seen for the period 1972-1973. As depicted in Fig. 1, there is an inverse correlation between the cosmic ray intensity and the solar activity measured by sunspot numbers (expected from Forbush's analysis). However, the maximum of cosmic ray intensity does not always occur at the sunspot minima.

Further, a linear positive correlation could be seen between the sunspot number $\left(\mathrm{R}_{\mathrm{z}}\right)$ and interplanetary magnetic field (B). However, the IMF, B maximum not always corresponds to the sunspot maxima. The IMF, B is found to inversely correlate with the cosmic ray intensity variation. To identify a possible correlation between these parameters, we have also calculated the correlation coefficient between these data strings for different solar cycles (20-23). We observed a significant inverse correlation between the cosmic ray intensity and $\mathrm{R}_{\mathrm{z}}$ for all the four mentioned solar cycles $(-0.78,-0.95,-0.86,-0.95)$. The IMF, B shows a weak negative correlation $(-0.35)$ with cosmic rays for solar cycle 20 , and a good anti-correlation for solar cycles $21-23(-0.76,-0.69)$. This parameter is found to be positively correlated with $\mathrm{R}_{\mathrm{z}}(0.53)$ and significantly correlated for the rest of solar cycles $21-23(0.68,0.90,0.61)$. 


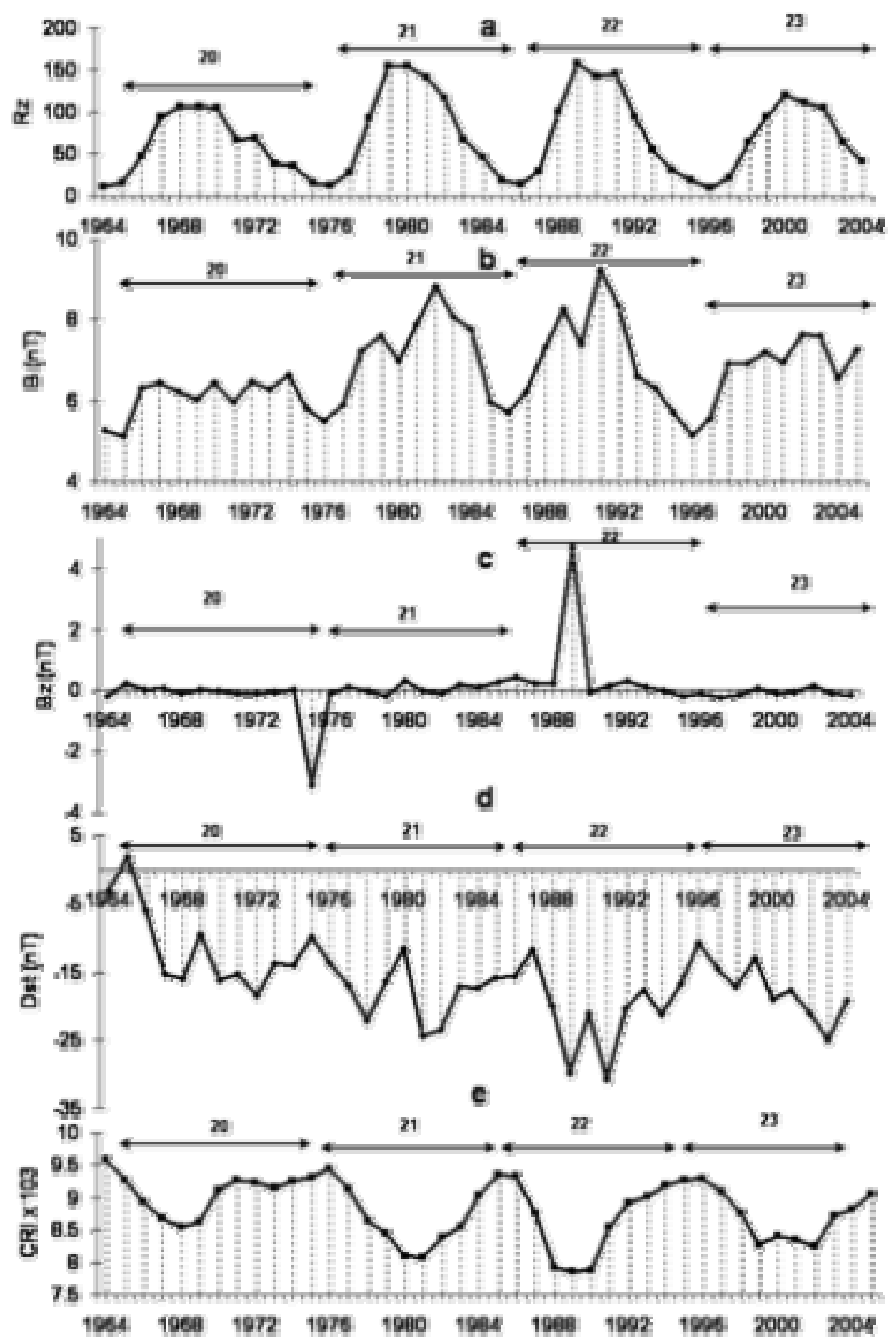

Fig. 1. Annual variation of cosmic rays along with $(a)$ sunspot numbers $\left(\mathrm{R}_{\mathrm{z}}\right) ;(b)$ interplanetary magnetic field (B); (c) north-south component of interplanetary magnetic field $\left(\mathrm{B}_{\mathrm{z}}\right)$; (d) disturbance storm time index $\left(\mathrm{D}_{\mathrm{st}}\right)$ during solar cycles 20-23;

(e) the normalized cosmic ray intensity

Thus, from the above findings one may conclude that for four different solar cycles the cosmic ray intensity has anti-correlation with the sunspot numbers $\left(R_{z}\right)$ and interplanetary magnetic field (B) with some discrepancy. 
The behaviour of cosmic rays and solar activity are qualitatively different during the descending phase of solar cycle 20 . The cosmic ray intensity was found to be independent of solar activity during 1973-1976. The correlation between IMF $\mathrm{B}$ and cosmic ray behaviour was also found very weak during solar cycle 20 . The cosmic ray modulation is controlled by the global solar activity affecting the conditions of cosmic ray propagation in the heliosphere. The very low solar activity in cycle 20 may be responsible for the unusual behaviour of cosmic rays and IMF parameters. This implies that the perturbations in heliosphere are weaker and less widely spread during solar cycle 20 than during other solar cycles. This might lead to a situation when the heliospheric perturbations are relatively small for cosmic ray particles, allowing them to reach the Earth as if it was a minimum solar activity period. This implies that the heliospheric perturbations caused by solar activity in the descending phase of solar cycle 20 were quite local and could not result in the global modulation of cosmic rays.

$\ddot{O}_{z g} \ddot{u} c ̧ \&$ Ataç [10] studied the hysteresis effect of the solar flare index and the cosmic ray intensity for the period from January 1, 1965 to December 31, 2001 on a daily basis. They have shown that a smoothed time series of the flare index and the daily Calgary Galactic Cosmic Ray intensity values exhibit significant solar-cycle-dependent differences in their relative variations during the studied period, and the shapes of these differences vary from cycle to cycle.

Van Allen [11] shows a plot of annual averages of sunspot numbers versus the climax cosmic-ray intensity, with different patterns for even- and oddnumbered solar cycles (broad ovals in cycles 19 and 21, narrow ovals (straight lines to first order) in cycles 20 and 22). Van Allen did not consider the tilt angle in his analysis. An earlier study by Nagashima \& Morishita [12] used the same technique as that of Van Allen, using the ionization chamber data from Huancayo. These authors found that the even-odd pattern in the relationship between sunspots and cosmic rays is also present (although not as clear) in the data from cycles 17 (the peak sunspot number in 1937) and 18 (1947).

\section{CONCLUSIONS}

From the present investigations the following conclusions can be drawn:

1) An inverse correlation exists between the cosmic ray intensity and the solar activity (measured by sunspot numbers $\left(\mathrm{R}_{\mathrm{z}}\right)$ ), as could be expected from Forbush's original analysis.

2) The interplanetary magnetic field strength (B) shows a weak negative correlation $(-0.35)$ with cosmic rays for solar cycle 20 , and a high anti-correlation for solar cycles $21-23(-0.76,-0.69)$.

3) The interplanetary magnetic field strength (B) shows a good positive correlation with the sunspot numbers for four different solar cycles.

\section{Acknowledgements}

The authors are indebted to various experimental groups, in particular, to Prof. Margret D. Wilson, Prof. K. Nagashima, Miss Aoi Inoue and Prof. J.H. King for providing the data. 


\title{
REFERENCES
}

1. Forbush, S.E. (1954). J. Geophys. Res., 59, 525.

2. Ahluwalia, H.S., \& Wilson, M.D. (1996). J. Geophys. Res. 101, 4879.

3. Jokipii, J.R., \& Thomas, B. (1981). Astrophy. J., 243, 1115.

4. Ahluwalia, H.S. (2000). Geophys. Res. Lett., 27, 1602.

5. Stozhkov, Y.I., Pokrevsky, P.E., \& Okhlophov, V.P. (2000). J. Geophys. Res., 105, 9.

6. Cliver, E.W., \& Ling, A.G. (2001). Astrophys. J. Lett., 551, L189.

7. Berezhko, E.G., Brevnova, I.A., \& Starodubtsev, S.A. (1993). Astronomy Letters, 19 (4), 304.

8. Starodubtsev, S.A. (1999). Astronomy Letters, 25 (8), 540.

9. Starodubtsev, S.A., \& Usoskin, I.G. (2003), Astronomy Letters, 29, 594.

10. Özgüç \& Ataç, T. (2003). New Astronomy, 8 (8), 745.

11. Van Allen, J.A. (2000) Geophys. Res. Lett., 27, 2453.

12. Nagashima, K. \& Morishita, I. (1980). Planet. Space Sci., 28, 195.

\section{GALAKTIKAS KOSMISKĀ STAROJUMU MODULĀCIJAS PĒDĒJO SAULES CIKLU KONTEKSTĀ}

\author{
R. Agarwal, R.K Mishra.
}

Kopsavilkums

Kosmiskie stari, kas iegūti neitronu monitoringā no dažādiem uz Zemes bāzētiem detektoriem, izmantoti, lai izpētītu galaktikas kosmisko staru modulācijas pēdējos četros Saules aktivitātes ciklos. Jau no seniem laikiem veikti sistemātiski korelatīvie pētījumi, lai noteiktu nozīmīgo korelāciju starp kosmisko staru intensitāti un dažādiem heliosfēriskās aktivitātes parametriem. Rakstā pētījums paplašināts ar pēdējo Saules ciklu (23.). Šajā rakstā gada vidējā Saules 10,7 cm radioviḷnu plūsma un starpplanētu magnētiskais lauks (SML) izmantoti, lai atrastu gada vidējās kosmisko staru intensitātes korelāciju, kas iegūta dažādos neitronu monitoros.

Noskaidrots, ka četros Saules ciklos (20-23) kosmisko staru intensitāte atrodas antikorelācijā ar Saules $0,7 \mathrm{~cm}$ radioviļ̣n plūsmu un SML (ar nelielu izkliedi). Tomēr tā ir laba korelācijā ar šo plūsmu četros dažādos Saules ciklos. SML rada vāju korelāciju ar kosmiskiem stariem 20. Saules ciklā un labu antikorelāciju 21-23. Saules ciklos.

05.08.2011. 